\title{
"Piores que bestas feras": Garcilaso de la Vega e o imaginário hispano-inca sobre os Guarani Chiriguano
}

\author{
Protasio Paulo Langer
}

Na historiografia da América colonial, os Chiriguano são reconhecidos como um dos grupos mais exitosos no enfrentamento defensivo e ostensivo de dois poderosos impérios: o incaico e o espanhol. ${ }^{1}$ A resistência armada dos Chiriguano perpassou todo o período colonial e só foi derradeiramente aniquilada em 1892, pelo exército da Bolívia. Na primeira metade do século XVI, quando da chegada dos espanhóis, esse grupo ocupava uma área de aproximadamente $100.000 \mathrm{~km}^{2}$ na atual Bolívia, numa zona de transição entre o Chaco e os Andes - Pie de Monte y subandina.

No presente trabalho pretendemos analisar o imaginário do Inca Garcilaso de la Vega sobre os Chiriguano. Esse recorte tem em vista que o referido cronista foi partícipe indireto das tentativas dos Inca em conquistar esse grupo; ele também foi contemporâneo dos empreendimentos militares do vice-rei Francisco de Toledo contra aquele império. Como filho de uma nobre mulher inca, conheceu os relatos orais sobre as conquistas militares do seu povo. Como filho de um conquistador espanhol teve uma esmerada formação humanista cristã e, desde a sua juventude até o fim da vida, cultivou profundo interesse pela história inca e pelas vicissitudes da colonização espanhola no Peru.

Considerando que a obra de Garcilaso, Comentarios reales de los Incas (1609), tornou-se um clássico da literatura hispano-americana, nossa atenção incide sobre a capacidade do autor de constituir um imaginário antropológico que lhe permitiu dialogar com dois universos simbólicos tão díspares quanto o inca e o espanhol. Neste sentido, transitando intensamente num mundo partido em dois polos, a obra de Garcilaso é perpassada por um imaginário sincrético em que a tradição indígena é, por um lado, filtrada pela literatura humanista cristã, e por outro, "serve de chave para melhor compreender o mundo do Renascimento". 2 Essa ambivalência se manifesta ao longo de toda a obra, inclusive na descrição dos Chiriguano.

Em se tratando dos povos chamados bárbaros, buscaremos perceber em que medida Garcilaso tece uma coincidência entre o imaginário inca e o humanista cristão, uma vez que tanto para espanhóis, quanto para os Inca, os Chiriguano eram um obstáculo à expansão política, um avesso de humanidade e, portanto, um alvo de conquista. Buscamos também compreender de que maneira a descrição dos Chiriguano serviu de pretexto ou ensejou um enaltecimento da história inca e uma crítica velada a governantes espanhóis sem, contudo, afrontar os fundamentos da colonização ibérica. Essas questões constituem o foco do nosso olhar sobre a crônica do Inca Garcilaso de la Vega.

A noção de imaginário que permeia nossa reflexão é a de um sistema de ideias/imagens, que participam do processo de tradução/representação da "realidade" que exorbita as fronteiras da experiência e dos encadeamentos "racionais". Este sistema, por um lado, atua sobre o real ao lhe atribuir significados e, por outro, é constantemente atualizado e reformulado pelas impressões que a experiência oferece aos sentidos e que, por sua vez, realimentam o sistema de ideias/imagens representativas. ${ }^{3}$

\section{O Inca Garcilaso e o vice-rei Toledo}

A biografia do autor revela aspectos essenciais para a compreensão crítica da sua narrativa. O Inca Garcilaso de la Vega era filho do aventureiro/conquistador Sebastián Garcí Lasso de la Vega Vargas que, a partir de 1534, participou da conquista do Peru e das guerras entre os próprios conquistadores, ao lado de Francisco Pizarro. Sua mãe era Chimpu Ocllo, uma princesa incaica que, depois de batizada, passou a se chamar Isabel Suárez. Essa princesa era neta do imperador inca Tupac Yupanqui (14711493) e prima de Huáscar que morreu na disputa do trono do império com seu irmão Atahualpa. 
Garcilaso nasceu em abril de 1539 e foi batizado com o nome Gómez Suárez de Figueroa, em homenagem a renomados antepassados da linhagem paterna. Sua língua materna - aquela que mamé em la leche $e^{4}$ o Quechua (Runa Simi), língua geral dos índios do Peru, a única que sua mãe sabia falar. Do nascimento até os vinte anos de idade conviveu com os conquistadores espanhóis e com os parentes da sua mãe, dos quais conheceu mais de duzentos, todos descendentes da família real incaica.

No decorrer da obra, o leitor é conduzido às visitas semanais que os parentes de sua mãe faziam à casa em que ele residia, em Cuzco. Nesses encontros os assuntos mais recorrentes eram a origem e a majestade dos imperadores (Inca), a grandeza do império, as conquistas, façanhas e leis dos governantes em favor de seus vassalos. O fragmento de sua narrativa, a seguir, permite inferir que os encontros assíduos da nobreza inca eram artifícios psicológicos, de teor catártico, acionados para atenuar o trauma da conquista espanhola. Naquelas reunióes seus parentes rememoravam o passado para gerar uma descarga emocional tornando o presente mais suportável:

Das grandezas e prosperidades passadas chegavam às coisas presentes: choravam seus reis mortos, alienado seu império e acabada sua república etc. Estas e outras semelhantes práticas tinham os Incas e Pallas em suas visitas. E com a memória do bem perdido, sempre acabavam sua conversação em lágrimas e pranto, dizendo: "Se nos trocou o reinar em vassalagem"...5

De acordo com Bernand e Gruzinski, o menino mestiço percebia confusamente que seus parentes mais antigos nunca aceitaram a conquista espanhola da qual seu pai foi protagonista. Além do mais,

surpreendia conversas onde se falava de Manco e da corte de Vilcabamba, dos esplendores do passado e da destruição de um modo de vida que os parentes de sua mãe recordavam com nostalgia. (...) Dividido entre sua mãe e seu pai, o jovem Gomes Suárez aprendeu as duas línguas; expressava-se em quíchua, como sua mãe, mas sua visão de mundo não era mais a de um índio. ${ }^{6}$

Todavia, para além da dicotomia familiar a presença dos seus parentes inca era benfazeja, pois se deleitava em ouvir histórias - "folgava em ouvi-las como folgam os que ouvem fábulas"” - e, a partir dos 16 ou 17 anos de idade, passou a demonstrar interesse especial pelas antiguallas dos Inca interrogando e interagindo diretamente com os parentes mais idosos que, por sua vez, esperavam que o sobrinho mestiço se tornasse o guardião da memória do seu povo. ${ }^{8}$ Em seus Comentarios, Garcilaso relembra com nostalgia esses tempos:

...em minha meninice me contavam suas histórias como se contam as fábulas aos meninos. Depois, em idade mais crescida me deram larga notícia de suas leis e governo, cotejando o novo governo dos espanhóis com o dos Incas, separando, particularmente, os delitos e o rigor das penas.

Diziam-me como procediam seus reis, na paz e na guerra: de que maneira tratavam seus vassalos e como eram servidos por eles. Além disso, me contavam, como se eu fosse seu próprio filho, toda a sua idolatria, seus ritos, cerimônias e sacrifícios, suas festas - principais e não principais - e como as celebravam. ${ }^{9}$

Com o falecimento do seu pai, em 1560, Gomez Suárez - ou seja, Garcilaso - viaja para a Espanha no intento de obter uma pensão pelos serviços que seu pai havia prestado à Coroa. Como não obteve tais benefícios, foi amparado por um tio paterno e mais tarde exerceu cargos militares, eclesiásticos (ordens menores) e, a partir de 1590, tornou-se escritor.

Garcilaso percebia que sua vida familiar em Cuzco, isto é, suas experiências "interculturais" vividas na infância e mocidade, seriam a marca distintiva de sua obra. Em relação aos demais escritores que historiaram os Inca no século XVI, sua contribuição seria mesmo a perspectiva êmica que ele reafirma diversas vezes, como no fragmento a seguir:

De maneira que não dizemos coisas novas, mas, que, como índio natural daquela terra, ampliamos e estendemos com o [nosso] próprio relato o que os historiadores espanhóis, como estrangeiros, reduziram por não saberem as propriedades da língua, nem haverem mamado no leite essa fábulas e verdades, como eu as mamei. ${ }^{10}$ 
Como mostra Gruzinski, nem a expressão "como índio natural daquela terra" e tampouco a adoção de um outro nome que ostentava sua indianidade - Inca Garcilaso de la Vega -, indicam um esforço de reaver uma identidade pré-hispânica, pois, "nem todas as reivindicações de identidade são formas de rejeição da nova ordem mundial". ${ }^{11}$

Já na Espanha, quando contava com 28 anos de idade, Don Francisco de Toledo tornou-se o vicerei do Peru e uma das suas obsessóes era demonstrar que o império incaico era considerado tirano e ilegítimo pelos povos andinos a ele sujeitados e que, no âmbito dos costumes e da religião, também era bárbaro. Sobre o governo inca, Toledo concluiu, a partir do depoimento de testemunhas, que, antes do estabelecimento do império inca não havia, entre os naturais, nenhum senhor, nem cacique nem qualquer espécie de sujeição. Topa Inca Yupanqui teria sujeitado tiranicamente todos os naturais, desde Cuzco até o Chile, e do Chile até Quito "fazendo-lhes guerra muito cruel, matando-os e assolando as terras e índios que não se lhe queriam sujeitar e reconhecê-lo por Senhor, e outras muitas crueldades...”."12

Em relação aos ritos religiosos, Francisco de Toledo encontrou elementos para provar que a religião inca era diabólica por praticarem sacrifícios humanos:

Prova-se que os ditos Incas tinham por costume sacrificar a seus deuses e ídolos os meninos e meninas mais bonitos, que não tivessem lepra, nem mancha, nem coisa feia em seu corpo; e os ditos indígenas os faziam matar, e enviavam [emissários] a cada província pedindo os ditos meninos para fazer o dito sacrifício... ${ }^{13}$

Em relação aos costumes e à vida política de povos submetidos ao Inca, o vice-rei diz provar que havia alguns dos Andes e Chunchos que comiam carne humana. ${ }^{14}$ Além do mais, ouviu dizer, que na província de Collao (Puno, às margens do Lago Titicaca), "havia alguns índios que cometiam o pecado nefando (sodomia), e que, para praticar este pecado, se vestiam como mulheres e se enfeitavam; algumas testemunhas dizem que (os Inca) os castigavam, e outras que não". ${ }^{15}$

Portanto, para melhorar o governo espiritual - a salvação das almas - e temporal - melhor aproveitamento da Fazenda Real -, os Inca e curacas (chefes indígenas) deveriam ser destituídos dos postos políticos em que vinham sendo mantidos, pois eram intrusos e tiranos. Sendo assim, o rei de Espanha, como único senhor legítimo do Peru poderia dar e repartir essas terras aos espanhóis sem qualquer escrúpulo. ${ }^{16}$ John Murra observa que os depoimentos coletados pelo vice-rei Toledo, a partir dos quais ele fundamenta suas conclusões, já "nasceram" corrompidos pelos propósitos a priori e pelo ambiente de hostilidade à História Inca. ${ }^{17}$

Esse modo de tratar a história do império incaico, à qual Garcilaso se sentia umbilicalmente filiado, deve ter desapontado profundamente o jovem mestiço que, da Espanha, mantinha-se plenamente informado sobre os desdobramentos políticos no Peru. Nesse contexto, em que diversas autoridades políticas e religiosas estavam engajadas em forjar um imaginário sobre o status humano e civilizacional do Novo Mundo, sobretudo dos povos andinos, surge a obra de Garcilaso, que não deixa de ser uma réplica às conclusōes desonrosas do vice-rei Toledo e dos seus cronistas oficiais. ${ }^{18}$

\section{A civilização dos bárbaros}

Na descrição etnográfica dos ameríndios, Garcilaso é duplamente "cêntrico": "incacêntrico", por reproduzir a convicção corrente entre os Inca, de que eles e os valores de seu império eram superiores frente às demais culturas; eurocêntrico, por admitir e legitimar a colonização hispânica dos povos ameríndios, inclusive dos Inca. A categorização etnográfica nos seus Comentarios manifesta esse duplo centrismo.

Como eram pensados e categorizados os Chiriguano e demais etnias indígenas pelo cronista hispano-inca? Primeiramente, vale observar que o discurso sobre a alteridade étnico/religiosa sempre aparece associado e filtrado pela noção de grau de civilidade. Nesse quesito, os Inca são o paradigma a partir do qual os demais povos do Peru pré-hispânico são avaliados. Transitando e dialogando com intelectuais 
de dois universos culturais, Garcilaso construiu um esquema explicativo no qual os povos andinos são inseridos em um plano hierárquico providencialista, no qual, aos Inca é assegurado o topo da civilidade pré-hispânica e aos inconquistáveis Chirihuanas é reservado o estrato mais inferior.

Para que se entenda melhor a idolatria, vida e costumes dos índios do Peru será necessário que dividamos aqueles séculos em duas idades: diremos como viviam antes dos Incas e, depois, como governaram aqueles reis, para que não se confunda um com o outro, nem se atribuam os costumes, nem os deuses, de uns aos outros. ${ }^{19}$

O surgimento dos Inca seria um divisor de idades. Na primeira idade situar-se-iam os povos anteriores, mas também os contemporâneos que ainda não haviam sido conquistados pelos Inca e tampouco pelos espanhóis. Entre os povos dessa primeira idade seria possível distinguir duas categorias: uns, “... pouco melhores que bestas mansas e outros, muito piores que bestas feras". ${ }^{20}$

O âmbito das crenças e práticas religiosas serve de referencial para explicar essa classificação. Os "mejores que bestias mansas" da idade pré-inca teriam ritos e crenças em conformidade com a vida simples que levavam. Para Garcilaso, a grande proliferação de divindades, ou ídolos, era própria da falta de centralidade política, pois, cada província, povo, bairro, linhagem e casa, tinha deuses diferentes, pelo entendimento de que o deus dos outros não poderia ajudá-los. ${ }^{21}$

Para o cronista, essa diversidade de divindades não deveria impressionar, pois os próprios gregos e romanos, orgulhosos de suas ciências, tiveram mais de trinta mil deuses. As idolatrias dessa primeira idade estariam relacionadas a um modo de vida rústico e selvagem e à falta de alguém que os "iluminasse", pois os povos estariam desamparados como ovelhas sem pastor. ${ }^{22}$

Todavia, a descrição acima não se refere aos Chiriguano, pois esses eram piores "que feras bravas":

Outras nações houve, como os Chiriguano (...), que não tiveram nem têm inclinação de adorar coisa alguma - baixa nem alta -, nem por interesse nem por medo, porque em tudo viviam e vivem [ainda] hoje como bestas. E piores, porque não chegou a eles a doutrina e o ensino dos reis Incas. ${ }^{23}$

Na perspectiva inca-eurocêntrica de Garcilaso, o pertencimento e a transição da primeira idade para a segunda idade é atemporal, pois o critério determinante não é cronológico e sim, político. A aceitação da doutrina oficial, a submissão às leis e à ordem do império e o pagamento de tributos (em serviços, no caso dos Inca) eram os elementos definidores de ascensão à segunda idade. Os Chiriguano, que resistiam ostensivamente às forças do império incaico continuavam, não apenas na primeira idade, mas também na subcategoria de "mucho peores que fieras bravas":

E destes há alguns, como são os do Cabo de Pasau e os Chiriguano e outras nações que não foram conquistadas pelos reis Incas, os quais estão hoje naquela rusticidade antiga. E esses, assim, são os piores de reduzir ao serviço dos espanhóis, como à religião cristã; como jamais tiveram doutrina, são irracionais e apenas têm língua para entenderem-se uns com outros, dentro de sua mesma nação. E assim vivem como animais de diferentes espécies, sem juntar-se nem comunicar-se nem tratar-se, se não apenas com os seus. ${ }^{24}$

Uma contribuição considerável para o estudo do imaginário inca sobre os "bárbaros", povos recalcitrantes ao poderio do império incaico, é o estudo de Cristiana B. Martins. A autora analisou as representações elaboradas por Guaman Poma de Ayala ${ }^{25}$ sobre os habitantes do Antisuyu, região que, de acordo com visão de mundo desse cronista, ficava ao norte de Cuzco e que, na lógica da cartografia ocidental, é situada à leste da capital inca, abrangendo uma extensa faixa amazônica e da região do Chaco. A partir da análise do mapa-múndi projetado por Poma de Ayala, Martins observa que:

De leste a oeste, toda a parte norte do mapa-múndi de Guaman Poma é dominada por uma densa barreira de árvores, rios caudalosos e uma fauna exuberante. Em El Primer Nueva Corónica y Buen Gobierno - e em diversas outras crônicas -, a ideia de um ambiente selvagem e não domesticado pelo homem, animais ferozes, canibalismo, ausência de civilização e ordem é desproporcionadamente relacionada ao Antisuyu. ${ }^{26}$ 
Poma de Ayala não trata diretamente dos Chiriguano. Todavia, sua representação sobre os povos do Antisuyo coincide extraordinariamente com o panorama (in)civilizacional ou caótico que Garcilaso traça da "Província Chirihuana" que, não por coincidência, se situa nos Antis (Antisuyu).

Se voltarmos nosso olhar para os escritores hispânicos que se ocuparam com o Novo Mundo, percebemos que classificar os povos quanto ao seu grau de civilidade e barbárie era uma tarefa usual e concomitante ao processo de conquista. Essa categorização era um âmbito da conquista propriamente dita; a conquista intelectual. O padre jesuíta José de Acosta, citado 54 vezes nos Comentários, classificou os povos bárbaros em três categorias: à primeira pertenceriam os chineses e japoneses, por possuírem "república estável, leis públicas, cidades fortificadas, magistrados obedecidos e o que mais importa, uso e conhecimento das letras, porque onde quer que haja livros e monumentos escritos, a gente é mais humana e política". ${ }^{27}$ Os chineses, por outro lado, seriam bárbaros, por andarem distanciados da recta razón, monopólio dos cristãos.

$\mathrm{Na}$ segunda categoria de bárbaros situavam-se os mexicanos e peruanos por não terem desenvolvido a escrita e, tampouco, conhecimentos filosóficos ou civis, muito embora tivessem república e magistrados, povoados estáveis, exércitos e uma forma solene de culto religioso. Também esses desconhecem a reta razão e "guardam tanta monstruosidade de ritos, costumes e leis" que se não forem constrangidos por um poder superior dificilmente receberão a luz do evangelho. ${ }^{28}$

À terceira classe de bárbaros pertenceriam "os selvagens semelhantes a feras, que apenas têm sentimento humano; sem lei, sem rei, sem pactos, sem magistrados nem república, que mudam a habitação, ou se a têm fixa, mais se assemelha a covas de feras ou cercas de animais". ${ }^{29}$ Dentre os povos incluídos nesta categoria, Acosta afirma que conhece os Chunchos, os Chiriguanos, os Mojos, os Yscaycingas por viverem próximos às fronteiras do Peru - a maior parte dos povos do Brasil e as etnias da Flórida, às quais os Astecas denominavam chichimecas. Mas, dentre os bárbaros da terceira categoria era necessário estabelecer distinções, pois nem todos eram sanguinários como tigres, embora se diferenciassem pouco dos animais, pois andavam desnudos e entregues aos vergonhosos delitos de luxúria e sodomia. ${ }^{30}$

Numa possível subdivisão da terceira categoria estariam os bárbaros mansos, "de entendimento muito curto, ainda que pareçam superar um pouco os anteriores, e tenham alguma sombra de república; porém suas leis, ou instituições, são pueris como brincadeiras" ${ }^{31}$. Mesmo assim, todos os bárbaros dessa macro terceira categoria seriam semi-humanos - nas palavras do autor, "hombres a medias" - e deveriam ser ensinados, como se fossem crianças, para que aprendessem a ser homens.

De acordo com Klaas Woortmann, esses sistemas classificatórios representam um reavivamento do esquema conceitual medieval da grande cadeia do ser. A partir dessa ideia os intelectuais procuravam a posição hierárquica de todos os seres da criação. "Para uns, tais selvagens não eram humanos; para outros, eram, mas não necessariamente tão humanos quanto os europeus; num caso como noutro, tornava-se preciso ordená-los, seja entre os humanos, seja entre os animais". ${ }^{32}$ Comparar, classificar e diferenciar os ameríndios eram formas de assimilá-los ao pensamento criacionista do humanismo cristão. Neste sentido, classificar é um ato de dominação simultâneo à conquista, pois,

qualquer forma de classificação implica uma redução do singular a um universal. Classificar para discriminar, discriminar para normatizar, normatizar para controlar, controlar para dominar, dominar classificando... Este é o círculo vicioso e asfixiante que produz qualquer classificação. ${ }^{33}$

Vale destacar que categorias antagônicas, tais como as que serviram aos cronistas coloniais, ainda rondam como espectros o imaginário científico-antropológico americano. Com distintas tipologias, carregadas de significados similares àqueles difundidos por cronistas andinos e por europeus quinhentistas, a antropologia evolucionista classificou as populações nativas da América do Sul "à sombra do Inca" ${ }^{34} \mathrm{O}$ império inca tornou-se o padrão a partir do qual as estruturas sócio-econômicas dos demais povos sul-americanos foram classificadas. Em ordem ascendente teríamos: marginais (bandos de caçadores e coletores); semi-marginais (bandos que praticariam uma agricultura incipiente); tribos (horti- 
cultores das florestas tropicais); cacicados e, finalmente, as altas civilizações, configurando uma série de degraus que as sociedades iriam transpondo, de forma ascendente, impulsionadas por leis evolucionistas de diversos matizes. Neste sentido, é possível perceber analogias entre as representaçôes antropológicas dos cronistas andinos (Guaman Poma de Ayala, Garcilaso de la Vega), dos cronistas europeus (José de Acosta) e dos antropólogos contemporâneos que, na esteira de Lewis H. Morgan, ordenaram as alteridades étnicas sul-americanas em estágios culturais evolutivos.

Voltando aos Comentários, a segunda idade da história dos Andes tem início quando um filho e uma filha do Sol são enviados do céu à terra (nas proximidades do Lago Titicaca) para civilizar e catequizar os povos. ${ }^{35}$ Nesses relatos, interessa analisar o caráter ideológico do imaginário religioso e civilizacional do império incaico, transmitido ao escritor, pelo tio materno. Dentre todos os que escreveram sobre o Peru, ninguém fez repercutir melhor esse ideário que Garcilaso:

Nosso pai o sol, vendo os homens como lhe tenho dito, se apiedou e teve lástima deles e enviou do céu à
terra um filho e uma filha dos seus, para que os doutrinassem no conhecimento de nosso pai, o sol, para
que o adorassem e o tivessem por seu deus. E para que lhes dessem preceitos e leis, em que vivessem como
homens, na razão e na urbanidade; para que habitassem em casas e povoados, soubessem lavrar as terras,
cultivar as plantas e colheitas, criar os gados e gozar deles e dos frutos da terra, como homens racionais e
não, como bestas. ${ }^{36}$

Entendemos que, no excerto acima e também nos seguintes, reside o filtro ideológico do Estado Inca, que permite classificar hierarquicamente os povos andinos: no mais alto patamar civilizacional andino estariam os filhos do sol e seus descendentes (a nobreza inca); em seguida, os outrora bárbaros ingênuos que, agora iluminados, se tornaram súditos do império; finalmente, os Chiriguano (e outros) que, pela hostilidade e insubmissão, figuram como selvagens bestiais. Assim sendo, a humanidade plena só seria alcançada pela submissão à esfera do poder político/religioso do império incaico.

A retórica de Garcilaso indica claramente que os preceitos e os procedimentos pedagógicos que deveriam orientar a implantação desse projeto de humanização dos povos andinos eram, por ele, estimados. A submissão dos bárbaros ao poder de um governo civil; a unidade religiosa de todo o império em torno de um Deus comum; a agricultura e a pecuária como premissas de uma vida urbana e racional eram princípios que estabeleciam afinidades entre os ideários, igualmente imperialistas, inca e hispânico e, como tal, deveriam ser admirados pelos leitores.

A descrição do mito fundador do império incaico, copioso em valores caros ao humanismo cristão, enseja uma proximidade dialógica entre a doutrina inca e o cristianismo. Vejamos as prescrições do Deus Sol a seus filhos:

Quando tenhais reduzido essas gentes a nosso serviço, ireis mantê-los na razão e na justiça, com piedade, clemência e mansidão, fazendo em tudo ofício de pai piedoso para com seus filhos ternos e amados, à imitação e semelhança minha que a todo mundo faço bem, que lhes dou minha luz e claridade para que vejam e façam seus haveres e lhes aqueço quando têm frio. [...] E tenho cuidado de dar uma volta cada dia ao mundo para ver as necessidades que na terra se oferecem, para provê-las e socorrê-las, como sustentador e benfeitor das gentes. ${ }^{37}$

À imitação do pai (o Sol), supremo bem, os filhos enviados ao mundo eram os guardiōes dos povos conquistados, os instrutores dos ofícios agrícolas e os protetores da humanidade redimida da barbárie. Em recompensa a esses serviços, o Deus Sol constituiu esse casal como reis e senhores de todos os povos que seriam doutrinados com boa razão, obras e governo. ${ }^{38}$

A formação cultural e religiosa mestiça é um dos aspectos que torna a obra do Inca Garcilaso de la Vega extraordinariamente interessante. Sustentar que sua catequese foi simultaneamente cristã e inca não significa que ele tenha praticado qualquer rito dos parentes do lado materno e, tampouco professado duas crenças simultaneamente. Sempre que o narrador é algum dos antigos Inca, o autor coloca o texto entre aspas e, quando teme que possa ser mal interpretado, faz advertências semelhantes a esta: 
"Advirta-se para que não enfade o repetir tantas vezes estas palavras 'nosso pai, o sol', que era linguagem dos Incas e modo de veneração e acatamento..." ${ }^{39}$

Embora seu relato não indique envolvimento ou cumplicidade em qualquer "heresia" indígena, Garcilaso percebe um sentido teleológico no império incaico e em sua doutrina. Sua concepção de história, dividida em primeira idade (barbárie, selvageria) e segunda idade (leis, razão, civilização), destina ao Inca o papel de precursor da verdadeira doutrina, da "Santa Madre la Iglesia Romana". O excerto a seguir expressa a compreensão de que o Deus cristão autorizou o surgimento da civilização inca para que ela iluminasse os povos andinos e os preparasse para receberem melhor a "verdadeira fé" - trazida pelos espanhóis:

Vivendo ou morrendo aquelas gentes, da maneira como vimos, permitiu Deus Nosso Senhor que deles mesmos saísse um luzeiro claro que, naquelas obscuríssimas trevas, lhes desse algumas notícias da lei e da urbanidade e respeito que os homens deviam ter uns com os outros, tornando-os capazes de razão e de qualquer boa doutrina, para que, quando esse mesmo Deus, Sol de justiça, tivesse por bem enviar a luz de seus divinos raios àqueles idólatras, encontrasse-os não tão selvagens, se não mais dóceis para receber a fé católica, o ensino e a doutrina da nossa Santa Mãe a Igreja Romana. ${ }^{40}$

Portanto, a concepção de idades históricas e o papel de precursor dos Inca no fluxo histórico, que culminou com a chegada dos espanhóis e da "verdadeira fé", parece ser uma importante chave hermenêutica para a análise da obra de Garcilaso. De acordo com ele, sob o jugo das leis do império incaico, os povos conquistados recebiam a luz da civilização e passavam a professar um sistema de crenças e valores assimilável pela religião cristã. Ao compelir os povos conquistados a adorar a um só deus ("nuestro padre, el sol"), em substituição às “abomináveis idolatrias", novamente o autor sintoniza imagens de profundo significado religioso, passíveis de serem compartilhadas por antigos inca e por cristãos.

As imagens do deus inca, pai e sol, servem ambas de metáfora para o Deus cristão. De acordo com Chamorro, na tradição cristã, Deus é um pai que ama seus filhos, é clemente, generoso e piedoso. Todavia, é também severo e castigador, a ponto de ser temido pelos seus. ${ }^{41}$ Para Garcilaso, essa face mais temível do Deus Pai Sol pairava ameaçadora apenas sobre os "bárbaros" que sofreriam as consequências caso resistissem à submissão política. Se para os Inca, o próprio astro era a divindade, para os cristãos o sol serve de metáfora, de extraordinário valor simbólico. O sol aquece, o sol é energia de vida, embora não seja deus. Para Garcilaso, não há imagem mais apropriada do que o sol para exprimir a concepção cristã de um ser supremo. Essa articulação do Deus inca servindo de metáfora ao Deus cristão teve por intuito, em nossa interpretação, mostrar para o público europeu, que a religião inca estava muito próxima da "verdadeira fé" e que nela não havia nada de diabólico.

O propósito de tornar o império incaico mais assimilável para os europeus foi percebido em diversos outros cronistas. De acordo com Martins, Poma de Ayala também representou as idades do mundo, a partir do projeto civilizador inca. As imagens de Poma destacam a ideologia de trabalho, progresso e obediência ao Inca como caminho de ascensão, de humanização. ${ }^{42}$ Esse zelo em retratar de maneira positiva a civilização inca - politicamente a mais suave, generosa e racional do Novo Mundo, ${ }^{43}$ moralmente íntegra e espiritualmente muito próxima da verdadeira fé -, de modo a contrastá-la com as imagens propagadas pelo vice-rei Toledo, merece ser situado no âmbito do eurocentrismo colonial que afligia os mestiços e os próprios nativos. Neste sentido, John Murra pondera que os escritores mestiços, como o Padre Blas Valera e Garcilaso de la Vega, escreviam para serem mais bem aceitos pelo público europeu e para que o povo ao qual pertenciam suas mães fosse melhor compreendido. Se por um lado, Murra lhes reconhece grandes conhecimentos sobre a cultura andina, por outro, recomenda que

os dois devem ser interpretados com grande cautela quando se referem a assuntos que eles consideravam que os europeus não entenderiam bem.(...)

Ambos elaboraram a história inca de tal maneira que parecesse mais longa e gloriosa. Finalmente os dois exageraram o grau de paternal benevolência assumido pelo Estado Inca para com seus cidadãos, enquanto que este mito contrastava com a dura realidade da exploração na qual ambos cresceram... ${ }^{44}$ 


\section{Um capítulo sobre os Chiriguano}

Na perspectiva de Garcilaso, os Chiriguano haviam representado, outrora, um desafio civilizacional aos Inca e, agora, ao império espanhol. O Capítulo XVII, do Libro Séptimo, intitulado "La Nación Chirihuana y su vida y costumbres" é dividido em três tópicos. O primeiro tematiza o espírito da conquista de novas províncias, o envio de espióes aos Chiriguano, o relatório geográfico e etnográfico dos espiōes e, finalmente as diligências e os resultados da guerra. O segundo tópico é uma interpolação sobre a campanha do vice-rei Francisco de Toledo contra os mesmos Chiriguano. O terceiro tópico pretende ser uma avaliação atualizada do estado dos daqueles indígenas, no tempo em que o autor escrevia sua obra.

O capítulo inicia explicando que, movido pelo desejo de conquistar novos reinos e províncias desejo este "tão natural nos homens poderosos" -, o Inca Yupanqui determinou empreender a conquista de uma grande província denominada Chirihuana. Após tomar essa decisão, o imperador deu início aos preparativos e, por se tratar de uma região desconhecida, o primeiro passo foi o envio de espiōes para observar, com cuidado e diligência, a terra e seus habitantes. $\mathrm{O}$ relatório desses agentes secretos permitiria planejar a expedição de conquista do exército de Tupac Inca Yupanqui. Em seu retorno, os agentes secretos do Inca disseram que:

a terra era malíssima, de montanhas bravas, lodo, lagos e pântanos e de muito pouco proveito para semear e cultivar. E que os nativos eram brutíssimos, piores que bestas feras, que não tinham religião nem adoravam coisa alguma, que viviam sem lei e bons costumes, tal como animais pelas montanhas, sem povoados, nem casas. ${ }^{45}$

É interessante observar que o relatório dos espiôes se inicia com uma análise geográfica; tudo indica, pois, que, neste aspecto, há uma similaridade entre a lógica inca e o pensamento ocidental. Além da íntima associação entre conhecimento geográfico e guerra, o relato de Garcilaso indica que, também para os Inca, a geografia é determinante do estado civilizacional dos povos. A população teria um caráter similar às terras que ocupa. Numa terra malíssima em que as montanhas bravas, os lodaçais, os pântanos inviabilizam a agricultura, é também inviável erigir ou mesmo infundir (introjetar) civilidade. Uma natureza de tal modo áspera e inóspita só poderia mesmo ser habitada por animais.

Não sabemos por quais meios, ou procedimentos, os espiões do rei inca obtiveram essas informações e tampouco poderemos nos deter em especulações sobre armadilhas da memória, ou reconstruções ideológicas da tradição oral que chegou até Garcilaso. No entanto, tudo indica que a descrição geográfica cumpre o papel de justificar o abandono da expedição do "bom Inca Yupanqui" e de exacerbar o barbarismo daquele grupo. Em todo caso, a descrição dos espiões sobre a Província dos Chirihuanas discrepa dos estudos etnográficos. Para Meliá:

De fato, a cordilheira, por suas condições climáticas especiais e pela fertilidade de seus vales, adapta-se muito bem à cultura de milho. (...) Esse bioma, portanto, favorece os cultivos guaranis típicos: milho, mandioca, feijão (kumanda) e abóbora (joco). Pode-se destacar que essa região, tanto pelo solo, quanto pelo clima e regime de chuvas, oferece condiçōes ideais para a produção de milho. ${ }^{46}$

Além do mais, bem antes de Garcilaso redigir sua crônica, a região ocupada pelos Chiriguano já era conhecida e ambicionada por colonos espanhóis que, a partir de 1560 (com a fundação de Santa Cruz de La Sierra), ali pretendiam instalar suas fazendas. Garcilaso (ou os espiões, ou os que narraram esse evento ao cronista) recusou-se a aceitar, ou não revelou, a agricultura dos Chiriguano para exagerar sua selvageria, da mesma forma como Vespúcio e Pigafetta ocultaram "a agricultura tupi, mantendo assim, ainda que por omissão, a relação simbólica entre selvagem e ausência de agricultura”. ${ }^{47}$ Partindo da documentação dos próprios colonizadores espanhóis, Pifarré observa que os Chiriguano possuíam níveis de produtividade agrícola "mais que satisfatórios". ${ }^{48}$ Colheitas abundantes, convites e festas que conferiam prestígio aos chefes, estavam na base das suas relações sociais, políticas e econômicas. 
Outro aspecto que vale ser analisado é a informação de que os Chiriguano não possuíam "pueblo ni casa". Não interessa, aqui, provar o contrário, mas seguir a linha de pensamento do nosso cronista. A ausência de casa assemelha-os mais às feras, pois denota a suposta incapacidade de engenho e a inexistência de convivência social. Vale destacar que Garcilaso aceita como verossímil e adota a versão dos espiôes, que chegou até ele aproximadamente sete décadas após o suposto episódio.

Todavia, no período em que Garcilaso produziu seus Comentarios já havia descrições etnológicas com um aporte empírico que examinavam as antigas versões da tradição oral da nobreza inca. ${ }^{49}$ Sem negar as notícias mais recentes, Garcilaso propõe que, a partir da expedição militar e civilizadora do Inca Yupanqui, os Chiriguano perderam parte da sua "inhumanidad" e aprenderam: "dos Incas, a fazer casas para sua morada. Não particulares, mas comunais, porque fazem um galpão grandíssimo e, dentro, tantos pequenos cômodos [apartadijos], quantos são os vizinhos". ${ }^{50} \mathrm{Se}$, por um lado, a explicação carece de consistência empírica, por outro, é reveladora da disputa ideológica em torno do caráter civilizado e civilizador dos Inca.

No entanto, é na descrição do suposto canibalismo que Garcilaso carrega as tintas para pintar um quadro macabro, misto de selvageria e monstruosidade. Miguel Rojas Mix sugere que, para os conquistadores do século XVI, havia uma similaridade semântica entre a noção de monstro e selvagem. Para Rojas Mix, monstro é aquele cuja fisionomia ou costumes se afastam das normas éticas e estéticas. "É difícil distinguir entre monstro e homem selvagem; ambos possuem todos os defeitos execrados pela sociedade civilizada, ambos representam a natureza frente à cultura". ${ }^{11}$ Vejamos, pois, o que disseram os espiōes:

E que comiam carne humana. E para obtê-la saíam a assaltar as províncias vizinhas e comiam todos os que prendiam, sem respeitar sexo nem idade. E bebiam o sangue quando os degolavam para que não se perdesse nada da presa. E que não somente comiam a carne dos vizinhos que prendiam, mas também a de seus próprios, quando morriam e que, depois de havê-los comido, voltavam a juntar-lhes os ossos pelas articulaçốes e os choravam e os enterravam em fendas de penhascos, ou ocos de árvores. ${ }^{52}$

A começar pela endoantropofagia, suposto tratamento dados aos parentes mortos, convém, mais uma vez, relacionar a descrição de Garcilaso com a visão de mundo de Poma de Ayala. Também neste aspecto os Chiriguano de Garcilaso coincidem com os habitantes dos Antis. As gravuras e a descrição de Poma indicam que, no Chinchaysuyu, Collasuyu e Cuntisuyu, os rituais de enterramento envolviam procissōes, tumbas e finas vestimentas, oferendas de alimentos e enfeites. Já no Antisuyo, os defuntos eram consumidos pelos familiares e seus ossos depositados em árvores esburacadas por vermes:

Como são índios da montanha que comem carne humana, assim que [alguém] cai defunto, logo começam a comê-lo não lhe deixando carne, somente ossos. [Antes], logo que acaba de dar o último suspiro, vestem [o defunto] com umas vestimentas [feitas] de penas; [depois] tiram-lhe as plumagens, despem-no, lavam-no, e começam a carnificina; [depois] tiram os ossos [...] e os metem em uma árvore que se chama uitaca, onde os vermes tinham feito um buraco. ${ }^{53}$

Essa similaridade entre os dois cronistas contemporâneos que, todavia, não se conheciam, indica que o imaginário de Garcilaso sobre os Chiriguano estava no âmbito do senso comum dos Incas sobre as etnias do Antisuyu. Portanto, a descrição de Garcilaso não se ampara em informações etnológicas de antigos e obscuros espiôes, mas em um imaginário vago, provavelmente compartilhado por toda uma tradição cultural do altliplano andino. Em relação à antropofagia, à ausência de cultura e à ferocidade natural, as analogias entre Antis e Chirihuanas também são abundantes. Garcilaso retrata um cenário em que a carne de qualquer ser humano próximo, sem distinção de sexo e idade, constituía a principal dieta desse grupo. Com costumes piores do que os das feras, os Chiriguano seriam, portanto, os antípodas da humanidade e da civilização. Vivendo em terras ásperas e estéreis ao extremo; sem casa, por falta de criatividade em construí-las; sem agricultura; alimentando-se apenas de carne humana; dificilmente um leitor da época tenha se deparado com um cenário mais macabro e bestial. 
No segundo e no terceiro tópicos, quando o autor fala a partir dele próprio (não mais a partir de histórias que ouviu na infância), a explicação para a antropofagia é ambígua: no segundo tópico, quando relata que o vice-rei Toledo escapou, por pouco, de ser devorado, essa prática é atribuída à falta de alimento, devido à esterilidade da terra: "São os Chiriguano (como se tem dito) muito ansiosos por comer carne, porque não a tem de nenhum tipo, doméstica nem selvagem, devido à muita ruindade da terra. E se tivessem conservado as vacas que o vice-rei lhes deixou, se poderia esperar que tivessem criado muitas...". ${ }^{54}$

Logo em seguida, no terceiro tópico, dá a entender que a índole da antropofagia é outra, uma vez que, se houvesse vacas, ainda assim prefeririam comer gente. "E são tão gulosos e apaixonados por comer carne humana que, quando saem a atacar (...) e encontram pastores guardando gado, mais querem um dos pastores do que toda porção de ovelhas ou vacas". ${ }^{55}$

Também em relação ao canibalismo, Garcilaso entende que a expedição militar dos Inca obteve um pequeno saldo benéfico: "Da pouca conversão e doutrina que os Inca puderam conseguir, da jornada passada, os Chiriguana perderam parte de sua desumanidade, porque se sabe que, desde então, não comem seus defuntos como estavam acostumados" ${ }^{56}$ Comendo ou não seus defuntos, seja por falta de opção alimentar, seja por preferirem carne humana às demais, o certo é que essa descrição tem diversos componentes do arquétipo do homem selvagem que se instalou no imaginário ocidental e acompanhou a odisseia dos europeus na exploração de mundos remotos.

Woortmann seguiu as pistas do homem selvagem desde a antiguidade grega, passando pelo medievo até o renascimento. Entre outras revelações interessantes, demonstrou que o canibalismo, o desconhecimento da agricultura, o habitar em terras estéreis e distantes, o comer cru etc, são atributos aplicados aos povos selvagens, míticos ou "reais", da antiguidade (ciclopes, amazonas e citas), do medievo (mongóis, sarracenos, irlandeses) e, em pleno renascimento, aos ameríndios. ${ }^{57}$

Neste sentido, em relação aos povos bárbaros, alvo de conquista dos impérios, o imaginário inca conflui com o imaginário ocidental. Se cruzarmos a iconografia e alguns relatos quinhentistas sobre a antropofagia dos Tupinambá, com a descrição do nosso cronista, perceberemos que uns e outros partilhavam de um imaginário similar. Manuela Carneiro da Cunha demonstrou que, a partir dos primeiros relatos de Colombo, seguidos pelos demais cronistas (missionários ibéricos, protestantes e católicos franceses), surgiram duas imagens emblemáticas sobre os indígenas comedores de carne humana: os canibais e os antropófagos.

Os primeiros eram bestas feras; já os antropófagos, que comiam seus inimigos por vingança, como Jean de Léry e André Thevet teriam presenciado no litoral brasileiro, eram aliados dos colonizadores tendo sido exaltados e consagrados por Michel de Montaigne como prova de uma sociedade igualitária e fraterna, cujas guerras eram tidas por nobres e generosas. ${ }^{58}$

Para ilustrar, a similaridade entre as imagens arquetípicas que compunham o sistema de representação acerca dos bárbaros bestas feras propomos uma comparação entre o texto de Garcilaso (acima) e a descrição de André Thevet sobre um (in)determinado grupo canibal do nordeste brasileiro:

Os canibais, cujas terras vão do Cabo de Santo Agostinho às proximidades do Maranhão, são os mais cruéis e desumanos de todos os povos americanos, não passando de uma canalha habituada a comer carne humana do mesmo jeito que comemos carne de carneiro, se não até mesmo com maior satisfação. E posso ainda assegurar que é custoso arrancar-lhes um prisioneiro das mãos depois que o agarram, tal é a avidez que têm para devorá-lo, parecendo leões famintos. Não há fera dos desertos d'África ou d'Arábia que aprecie tão ardentemente o sangue humano quanto estes brutíssimos selvagens. ${ }^{59}$

Além da ferocidade, da predileção pela carne humana em relação a qualquer outra, vale destacar que uns e outros são descritos como avessos a qualquer contato com outros povos e inimigos terríveis dos europeus. Em termos de valores humanos eram considerados inapropriados para qualquer forma de aliança. Portanto, dependendo do grau de amizade, ou de resistência, os povos que comiam carne humana podiam tanto ser bons selvagens, como os Tupinambá da costa brasileira, ou ainda como os 
Cário e Itatine, aliados dos conquistadores espanhóis do Rio da Prata (descritos positivamente por Irala, Schmidel e Cabeza de Vaca), ou selvagens bestiais (Caribas, Chunchos, Antis, Chiriguanos) inconquistáveis e irredutíveis.

$\mathrm{Na}$ descrição de Garcilaso o canibalismo chiriguano não tinha qualquer dimensão antropológica valores morais ou espirituais. Tinha sim, outras perversidades associadas a esse modo de vida animalesco. No mesmo parágrafo em que relata a antropofagia, Garcilaso apresenta a incestuosa e desregrada conduta sexual: "E que andavam nus em pêlo e que para juntarem-se no coito não se preocupavam se [as mulheres] eram irmãs, filhas nem mães. E que esta era a maneira comum de viver da nação Chiriguana". ${ }^{60}$

Em diversas outras crônicas quinhentistas e seiscentistas a promiscuidade sexual, o incesto e a sodomia são práticas percebidas como conjugadas ao canibalismo animalesco dos selvagens. Frei Reginaldo de Lizarraga, contemporâneo de Garcilaso, ao descrever os Chiriguano, também articulou, num mesmo parágrafo, a sodomia, o incesto e o canibalismo: "Não obedecem a um ponto sequer, do direito natural; são maldosos, tocados do vício nefando, e não perdoam a suas irmãs; é gente soberbíssima; dizem que todas as nações são seus escravos. Comem carne humana sem nenhum asco; andam nus" ${ }^{61}$ Como já referimos, o jesuíta José de Acosta, ao comentar a terceira classe de bárbaros afirma que os Chiriguano, e muitos outros, "devoram carne humana, andam nus (...) entregues aos mais vergonhosos delitos de luxúria e sodomia". ${ }^{62}$

A associação entre canibalismo e depravação sexual foi observada por Raminelli, ao estudar as imagens que Theodor de Bry produziu para ilustrar as crônicas quinhentistas de Hans Staden e Jean de Léry. Numa das pranchas uma índia "está com o dedo na boca e olha para as carnes (humanas) expostas, demonstrando o desejo de servir-se de mais um pedaço. A mesma índia tem sua mão esquerda na virilha, gesto este com forte conotação sensual". ${ }^{63}$ Ainda sobre as gravuras de Theodor de Bry, Woortmann considera que:

Aquela iconografia também mostra mulheres, imitadas curiosamente por um macaco, mordendo os próprios dedos e braços enquanto martirizam o prisioneiro destinado ao repasto canibal. Na mesma prancha é retratada uma mulher masturbando a outra. Em outra prancha uma mulher se masturba durante o repasto canibal. ${ }^{64}$

Em suma, perversão sexual e canibalismo compõem um dueto sinistro que, em geral, os cronistas atribuem não aos índios pacíficos - amigos, bons selvagens - mas, sim, às bestas feras. Algumas vezes, quando os pacíficos aliados apresentam condutas sexuais depravadas, na perspectiva da moral do colonizador, surgem explicações que tendem a absolvê-los, na medida em que condenam aos canibais. Para Michele de Cuneo, que acompanhou Colombo em sua segunda viagem às ilhas do Caribe, a sodomia dos índios mansos é culpa dos ferozes canibais que comiam àqueles, no duplo sentido da palavra, como demonstra Antonello Gerbi:

Até para a sodomia Michele da Cuneo encontra uma explicação racional: os mansos "índios" tinham contraído "este maldito vicio" com os ferozes canibais, que "subjugando os ditos Índios e comendo-os", fizeram-no "por desprezo"; "... aquele desregramento, em seguida," pode ter "crescido de um para o outro". Em suma, acabaram gostando. ${ }^{65}$

Que procedimentos, que sanções, ou ações civilizatórias, poderiam ser aplicadas a povos com comportamentos de tal modo monstruosos, diante dos quais até os mais promíscuos e sanguinários conquistadores poderiam se sentir beatos? No âmbito da ação político-civilizatória, em relação a esse gênero de bárbaros, também parece haver uma considerável sintonia, uma confluência entre os procedimentos do Estado Inca e dos conquistadores ibéricos. De acordo com Garcilaso, o imperador Yupanqui, após ouvir o relato dos espiōes, teria proferido as seguintes palavras: "Agora é maior e mais forçosa a obrigação que temos de conquistar os Chiriguano para tirá-los das torpezas e bestialidades em que vivem e reduzi-los à vida de homens, pois para isso nos enviou nosso pai, o sol" ${ }^{66}$ Não seria essa uma declaração de "guerra justa" abençoada pelo Deus Inca, com motivaçôes similares às guerras sancionadas e aplica- 
das pelos ibéricos aos povos ameríndios que resistiam à conquista temporal e espiritual? No presente artigo não iremos nos ocupar dessa possível analogia, apenas evocá-la como mais um componente do imaginário sincrético de um cronista que teceu uma trama para aproximar dois mundos, duas historicidades e duas crenças.

\section{Considerações finais}

Em relação às imagens que Garcilaso apresentou e atribuiu ao império inca e aos Chiriguano, creio que o aspecto político-identitário é de grande relevância e convém situá-las no âmbito da disputa pelo controle do imaginário sobre o Novo Mundo, nos termos propostos por Baczko.

O controle do imaginário social, da sua reprodução, difusão e manejo, assegura em graus variáveis uma real influencia sobre os comportamentos e as actividades individuais e colectivas, permitindo obter os resultados práticos desejados, canalizar as energias e orientar as esperanças. ${ }^{67}$

Não pretendemos discorrer sobre qual imaginário - o do vice-rei Toledo, ou o de Garcilaso - foi mais bem sucedido, assimilado e praticado politicamente no Peru colonial. Porém, ao longo dos séculos, apesar das recentes críticas das ciências humanas, a obra de Garcilaso repercutiu bem mais no pensamento ocidental sobre os Inca, que a de seu desafeto Toledo. Uma possível explicação pode ter sido a intenção declarada do vice-rei de fundamentar práticas políticas para beneficiar os colonos espanhóis, enquanto o cronista hispano-inca dissimulava a dimensão política das suas declaraçóes em sua reiterada autoridade em História e cultura inca, por havê-las mamado "en la leche".

A disputa pelo controle do imaginário deslizou por diversos temas. Em relação à conquista dos Chiriguano, os Inca se retiraram, não por terem sido derrotados, mas, por perceberem, após dois anos de esforços em vão, que havia coisas mais importantes a serem realizadas. Já o vice-rei Toledo, que intentou conquistá-los a ferro e fogo, saiu fracassado e humilhado. Teve que abandonar a liteira em que era carregado, seus suprimentos e toda a sua tralha de guerra para que os Chiriguano se contentassem com esses despojos, enquanto ganhava tempo para a fuga. Ainda assim, teve que ouvir ameaças e insultos dos próprios Chiriguano, nos seguintes termos: "Soltai essa velha que levais nessa petaca [liteira] que aqui a comeremos viva". ${ }^{68}$

No presente texto nosso propósito não foi oferecer aportes etnológicos sobre os povos guarani falantes, nos domínios do império incaico, historicamente conhecidos como Chiriguano. Em relação a esse tema, a obra de Garcilaso é de pouco ou nenhum proveito. Porém, consideramos que, para a história do imaginário inca e também do imaginário ocidental cristão, sobre as alteridades étnicas tidas por bárbaras, a obra de Garcilaso é uma fonte ímpar, na medida em que estabelece relações entre referências de pensamento tão díspares e ao mesmo tempo tão similares. Embora os Chiriguano não sejam tematizados a partir de dados propriamente empíricos, a descrição do cronista hispano-inca permite que nos aproximemos da imagem mental dos civilizados (Incas e Espanhóis) sobre esses e outros bárbaros - suas subdivisóes, seu status na hierarquia humana, os projetos político-pedagógicos para submetê-los etc.

Finalmente, pela obra de Garcilaso apreendemos melhor os desdobramentos dos imaginários em atitudes e práticas políticas que atravessam os séculos. Até hoje, somos tributários de uma visão romântica e idílica sobre o império incaico ${ }^{69}$ e estamos longe de conferir aos povos sem Estado o mesmo status humano que concedemos às "grandes civilizações". De acordo com Isabelle Combès, esse imaginário ainda marca as ciências humanas dividindo os pesquisadores: "a los historiadores, los Inca; a los antropólogos los Chiriguano!" ${ }^{70}$ 
"Piores que bestas feras": Garcilaso de la Vega e o imaginário hispano-inca sobre os Guarani Chiriguano Protasio Paulo Langer

\section{Notas}

${ }^{1}$ Diversos autores abordam esse tema, entre os quais destacamos: PIFARRÉ, Francisco. Los Guarani Chiriguano: historia de un pueblo. La Paz: Cipca, 1989; SAIGNES, Thierry. Historia del pueblo chiriguano. Introdução e notas de Isabelle Combés. La Paz: Plural, 2007; WACHTEL, Nathan. Os índios e a conquista espanhola. In: BETHELL, Leslie (Org.). História da América Latina: América Latina Colonial. São Paulo: Edusp; Brasília; Funag, 1998, p. 135-194.

${ }^{2}$ GRUZINSKI, Serge. O pensamento mestiço. Trad. Roberto Freire d'Aguiar. São Paulo: Companhia das Letras, 2001, p. 14.

${ }^{3}$ Entre as leituras que concorreram para a elaboração dessa concepção, destacamos PATLAGEAN, Evelyne. A história do imaginário. In: LE GOFF, Jaques. A história nova. São Paulo: Martins Fontes, 1990; PESAVENTO, Sandra Jatahy. Em busca de uma outra história: imaginando o imaginário. Revista Brasileira de História, São Paulo, v. 15, no 29, 1995 e RUIZ, Castor M. M. Bartolomé. Os paradoxos do imaginário. São Leopoldo: Unisinos, 2003.

${ }^{4}$ GARCILASO DE LA VEGA, Inca. Comentarios reales de los Incas. (1609). Edição, prólogo, índice analítico e glossário Carlos Araníbar. Lima: FCE, 1991, p. 132.

${ }^{5}$ No original: “De las grandezas y prosperidades pasadas venían a las cosas presentes: lloraban sus reyes muertos, enajenado su imperio y acabada su república, etc. Estas y otras semejantes pláticas tenían los Incas y Pallas en sus visitas. Y con la memoria del bien perdido siempre acababan su conversación en lágrimas y llanto, diciendo: 'Trocósenos el reinar en vasallaje’...”. GARCILASO DE LA VEGA, Inca. Op. cit., p. 40. Tradução nossa.

${ }^{6}$ BERNAND, Carmen \& GRUZINSKI, Serge. História do novo mundo: da descoberta à conquista, uma experiência europeia (1492-1550). 2.ed. São Paulo: EDUSP. 2002, p. 559.

${ }^{7}$ No original: "me holgaba de oírlas como huelgan los tales de oír fábulas. GARCILASO DE LA VEGA, Inca Op. cit., p. 40. Tradução nossa.

${ }^{8}$ Neste sentido, a obra de Garcilaso pode ser considerada uma reformulação das explicaçôes históricas incas, expressas com conceitos tradicionais, para dar conta dos novos tempos coloniais. Essa discussão foi proposta por Eduardo Natalino dos Santos / Revista de História 150 (1º - 2004). p. 198-199.

${ }^{9}$ No original: “...en mis niñeces me contaban sus historias cómo se cuentan las fábulas a los niños. Después, en edad más crecida me dieron larga noticia de sus leyes y gobierno, cotejando el nuevo gobierno de los españoles con el de los Incas, dividiendo en particular los delitos y las penas y el rigor de ella. Decíanme cómo procedian sus reyes, en paz y en guerra: de qué manera trataban a sus vasallos y cómo eran servidos de ellos. Además de esto me contaban como a propio hijo toda su idolatría, sus ritos, ceremonias y sacrificios, sus fiestas - principales y no principales - y cómo las celebraban”. GARCILASO DE LA VEGA, Inca. Op. cit., p. 49. Tradução nossa.

${ }^{10}$ No original: "De manera que no decimos cosas nuevas, sino que, como indio natural de aquella tierra ampliamos y extendemos com la propia relación lo que los historiadores españoles, como extranjeros, acortaron por no saber la propiedad de la lengua ni haber mamado em la leche aquestas fábulas y verdades como yo las mamê". GARCILASO DE LA VEGA, Inca. Op. cit., p. 94. Tradução nossa.

${ }^{11}$ GRUZINSKI, 2001. Op. cit., p. 16.

${ }^{12}$ No original: “... haciendoles muy cruda guerra y matandolos y asolando las tierras e indios que no se le querian sujetar y reconocerlo por Señor, y otras muchas crueldades...”. MONTESINOS, Fernando de. Memorias Antiguas Historiales y politicas del Perú. Cuidada por D. Marcos Jiménez de la Espada (1644). Madrid: Imprenta de Miguel Ginesta, 1882. p. 188. Tradução nossa.

${ }^{13}$ No original: "Prueba-se que los dichos Ingas tenian por costumbre de sacrificar á sus dioses é idolos los niños y niñas más hermosos y que no tuviesen lepra ni ninguna mancha ni cosa fea en su cuerpo; y los dichos indígenas los hacian matar, y enviaban a cada provincia á pedir los dichos indios niños para hacer el dicho sacrificio...". MONTESINOS, Fernando de. Op. cit., p. 195. Tradução nossa.

${ }^{14}$ MONTESINOS, Fernando de. Op. cit., p. 199.

${ }^{15}$ No original: "habia algunos indios que cometian el pecado nefando (sodomia), y que, para usar deste pecado, se vestian como mujeres y se afeitaban; algunos testigos dicen que (os Inca) los castigaban, y otros que no. MONTESINOS, Fernando de. Op. cit., p. 199-200. Tradução nossa.

${ }^{16}$ MONTESINOS, Fernando de. Op. cit., p. 201.

${ }^{17}$ MURRA, John. El Tawantinsuyu. In: RABIELA, Teresa Rojas; MURRA, John (Eds.). Historia general de América Latina: Las sociedades originarias. Vol. 1. Paris: UNESCO, 1999. p. 483.

${ }^{18}$ Galindo avaliou, nestes termos, a obra em análise: "El relato está guiado no solo por la preocupación de atener-se a los hechos, respetar a las fuentes, decir la verdad, sino además por el convencimiento de que la história puede ofrecer modelos éticos. Fue un historiador platónico convencido que sobre el passado es posible realizar un discurso político pertinente para el futuro. [...] Pero este libro respondia también a una conyuntura. Era un texto polémico destinado a enfrentar a los cronistas toledanos". FLORES GALINDO, Alberto. Buscando un inca: identidad y utopia en los Andes. Habana: Casa de las Américas, 1986. p. 54-55. 
${ }^{19}$ No original: "Para que se entienda mejor la idolatría, vida y costumbres de los indios del Perú será necesario dividamos aquellos siglos en dos edades: diremos como vivían antes de los Incas y luego diremos cómo gobernaron aquellos reyes, para que no se confunda lo uno con lo otro ni se atribuyan las costumbres ni los dioses de los unos a los otros". GARCILASO DE LA VEGA, Inca. Op. cit., p. 28. Tradução nossa.

${ }^{20}$ No original: "poco mejores que bestias mansas y otros mucho peores que fieras bravas". GARCILASO DE LA VEGA, Inca. Op. cit., p. 28. Tradução nossa. Grifo nosso.

${ }^{21}$ Idem, ibidem, p. 29.

${ }^{22}$ Idem, ibidem, p. 29.

${ }^{23}$ No original: "Otras naciones hubo como son los Chirihuanas [...], que no tuvieran ni tienen inclinación de adorar cosa alguna - baja ni alta - ni por interés ni por miedo, sino que en todo vivian y viven hoy como bestias. Y peores, porque no llegó a ellos la doctrina y ensenãnza de los reyes Incas". GARCILASO DE LA VEGA, Inca. Op. cit., p. 31. Tradução nossa.

${ }^{24}$ No original: " $Y$ de estos hay algunos, como son los del cabo de Pasau y los Chirihuanas y otra naciones que no conquistaron los reyes Incas, los cuales se están hoy en aquella rusticidad antigua. Y estos tales son los peores de reducir, asi al servicio de los españoles como a la religión cristiana, que como jamás tuvieron doctrina son irracionales y apenas tienen lengua para entender-se unos con otros dentro de su misma nación. $Y$ asi viven como animales de diferentes especies, sin juntarse ni comunicarse ni tratarse sino a sus solas”. GARCILASO DE LA VEGA, Inca. Op. cit., p. 31. Tradução nossa.

${ }^{25}$ As poucas informações existentes sobre Poma Ayala nos foram legadas por ele próprio. Seu pai teria pertencido a uma família nobre de Huánuco, na atual região de Ayacucho e sua mãe teria sido filha de Tupac Yupamqui, o décimo inca. Portanto, ele era um indígena de família nobre que durante a infância aprendeu a ler e escrever e foi introduzido à fé cristã. "Anos mais tarde [...] trabalhou como intérprete para os espanhóis, além de ter se engajado em ensinar espanhol para os nativos na tentativa de ajudá-los a se defender dos europeus e ao mesmo tempo resistir à colonização". MARTINS, Cristiana Bertazoni. Representaçôes do Antisuyu em El primer nueva corónica y buen gobierno de Felipe Guaman Poma de Ayala. Revista de História, 153 (20 - 2005). p. 123.

${ }^{26}$ MARTINS, Cristiana Bertazoni. Op. cit., p. 128.

${ }^{27}$ No original: “... república estable, leyes públicas, ciudades fortificadas, magistrados obedecidos y lo que más importa, uso y conocimiento de las letras, porque dondequiera que hay libros y monumentos escritos, la gente es más humana y política". ACOSTA, José de. De Procuranda Indorum Salute. (1577). Reeditada sob o título Predicación del evangelio en las indias. Estudio preliminar y edición del P. Francisco Mateos. Madrid: Atlas, 1954. Proemio. Disponível em: <http://www.cervantesvirtual.com/ servlet/SirveObras/mcp/01361686433460613088024/p0000001.htm>. Tradução nossa.

${ }^{28}$ ACOSTA, José de. Op. cit.

${ }^{29}$ No original: “... los salvajes semejantes a fieras, que apenas tienen sentimiento humano; sin ley, sin rey, sin pactos, sin magistrados ni república, que mudan la habitación, o si la tienen fija, más se asemeja a cuevas de fieras o cercas de animales”. ACOSTA, José de. Op. cit. Tradução nossa.

${ }^{30}$ ACOSTA, José de. Op. cit.

${ }^{31}$ No original: “... de muy corto entendimiento, aunque parecen superar algo a los anteriores, y tienen alguna sombra de república, pero son sus leyes o instituciones pueriles y como de burlas. ACOSTA, José de. Op. cit. Tradução nossa.

32 WOORTMANN, Klaas. O selvagem e o Novo Mundo: ameríndios humanismo e escatologia. Brasília: UNB, 2004 , p. 126.

${ }^{33}$ RUIZ, Castor M. M. Bartolomé. Os paradoxos do imaginário. São Leopoldo: Unisinos, 2003, p. 21.

${ }^{34}$ A expressão é de Carlos Fausto. A crítica à antropologia evolucionista também se baseia em seu trabalho, Os indios antes do Brasil (Rio de Janeiro: Jorge Zahar, 2000. p. 10-16).

${ }^{35}$ Aqui cabe uma observação secundária no conjunto da nossa análise: o conteúdo dos relatos dos parentes mais idosos permite inferir que paralelamente à escola e à catequese cristã em Cuzco, Garcilaso foi catequizado também por anciãos "hereges" no seio da sua família, quando já haviam passado mais de vinte anos da conquista espanhola.

${ }^{36}$ No original: "Nuestro padre el sol, viendo los hombres como te he dicho, se apiadó y tuvo lástima de ellos y envió de cielo a la tierra un hijo y una hija de los suyos para que los doctrinasen en el conocimiento de nuestro padre el sol para que lo adorasen y tuviesen por su dios. Y para que les diesen preceptos y leyes en que viviesen como hombres en razón y urbanidad, para que habitasen en casas y pueblos poblados, supiesen labrar las tierras, cultivar las plantas y mieses, criar los ganados y gozar de ellos y de los frutos de la tierra como hombres racionales y no como bestias". GARCILASO DE LA VEGA, Inca. Op. cit., p. 41. Tradução nossa.

${ }^{37}$ No original: "Cuando hayáis reducido esas gentes a nuestro servicio los mantendrés en razón y justicia, con piedad, clemencia y mansedumbre haciendo en todo oficio de padre piadoso para con sus hijos tiernos y amados, a imitación y semejanza mía que a todo mundo hago bien: que les doy mi luz y claridad para que vean y hagan sus haciendas y les caliento cuando tienen frío. [...] $Y$ tengo cuidado de dar una vuelta cada día al mundo para ver las necesidades que en la tierra se ofrecen, para proveerlas y socorrerlas como sustentador y bienhechor de las gentes". GARCILASO DE LA VEGA, Inca. Op. cit., p. 41. Tradução nossa.

${ }^{38}$ Idem, ibidem, p. 42. 
"Piores que bestas feras": Garcilaso de la Vega e o imaginário hispano-inca sobre os Guarani Chiriguano Protasio Paulo Langer

${ }^{39}$ No original: "Adviértase, para que no enfade el repetir tántas veces estas palabras "nuestro padre el sol" que era lenguaje de los Incas y manera de veneración y acatamiento...”. GARCILASO DE LA VEGA, Inca. Op. cit., p. 41. Tradução nossa.

${ }^{40}$ No original: "Viviendo o muriendo aquellas gentes de la manera que hemos visto, permitió Dios Nuestro Señor que de ellos mismos saliese un lucero del alba que en aquellas oscurísimas tinieblas les diese algunas noticias de la ley y de la urbanidad y respeto que los hombres debian tenerse unos con otros haciéndoles capaces de razón y de cualquiera buena doctrina, para que cuando ese mismo Dios, Sol de justicia, tuviese por bien de enviar la luz de sus divinos rayos a aquellos idólatras, los hallase no tan salvajes, sino más dóciles para recibir la fe católica, la enseñanza y la doctrina de nuestra Santa Madre la lglesia Romana". GARCILASO DE LA VEGA, Inca. Op. cit., p. 39. Tradução nossa.

${ }^{41}$ Sobre as representaçôes do divino na tradição cristã, indicamos o artigo de CHAMORRO, Graciela. Teologia e representação: uma aproximação ecofeminista do monoteísmo. In: REIMER, Ivoni Richter. Imaginários de divindade. Goiânia: UCG; São Leopoldo: Oikos, 2008. p. 49-100.

${ }^{42}$ MARTINS, Cristiana Bertazoni. Op. cit., p. 127.

${ }^{43}$ GARCILASO DE LA VEGA, Inca. Op. cit., p 277.

${ }^{44}$ MURRA, John. A estrutura política inca. In: BELLOTO, Manoel Lelo \& CORRÊA, Anna Maria Martinez. A América Latina de colonização espanhola. São Paulo: Hucitec, 1991. p. 28-29.

${ }^{45}$ No original: "la tierra era malísima, de montañas bravas, ciénagas, lagos y pantanos y muy poca de ella de provecho para sembrar y cultivar. Y que los naturales eran brutísimos, peores que bestias fieras, que no tenían religión ni adoraban cosa alguna, que vivian sin ley ni buena costumbre sino como animales por las montañas, sin pueblos ni casas”. GARCILASO DE LA VEGA, Inca. Op. cit., p. 459. Tradução nossa.

${ }^{46}$ No original: "De hecho, la cordillera, por sus especiales condiciones climáticas y la fertilidad de sus valles se adapta excelentemente a uma cultura de maíz. (...) Como se vê este bioma favorece los cultivos típicos guarani, de maíz, yuca, frijoles (kumanda) y calabazas (joco). Se puede señalar que esta zona, tanto por su suelo como por sus precipitaciones y clima ofrece condiciónes óptimas para la producción de maíz”. MELIÁ, Bartomeu. Los Guarani Chiriguano: Nande Reko nuestro modo de ser y bibliografia general comentada. La Paz: CIPCA, 1988. p. 33-34. Tradução do editor.

${ }^{47}$ WOORTMANN, Klaas. Op. cit., p. 171.

${ }^{48}$ PIFARRÉ, Francisco. Op. cit., p. 42.

${ }^{49}$ Frei Reginaldo de Lizárraga esteve no território chiriguano e descreveu a aldeia nos seguintes termos: "El mayor de los pueblos es de cinco casas; lo común es de tres; mas son muy largas, de más de 150 pasos, a dos aguas, con estantes en el medio sobre que se arma la cumbrera, y de estante a estante vive una parentela". LIZÁRRAGA, Reginaldo de. Descripción colonial (libro primero). (1605). Buenos Aires: Librería La Facultad, por Juan Roldán, 1916, p. 259.

${ }^{50}$ No original: “...de los Incas, a hacer casas para su morada. No particulares sino en común, porque hacen un galpón grandísimo $y$ dentro tantos apartadijos cuantos son los vecinos”. GARCILASO DE LA VEGA, Inca. Op. cit., p. 461. Tradução nossa.

${ }^{51}$ ROJAS MIX, Miguel. Los monstruos: ¿mitos de legitimación de la conquista? In: PIZARRO, Ana. América Latina: palavra, literatura e cultura. São Paulo: Memorial; Campinas: Unicamp, 1993. p. 127.

${ }^{52}$ No original: "Y que comían carne humana. Y para haberla salian a saltear las provincias comarcanas y comían todos los que prendían, sin respetar sexo ni edad. Y bebian la sangre cuando los degollaban para que no se les perdiese nada de la presa. Y que no solamente comian la carne de los comarcanos que prendian, sino también la de los suyos propios cuando se morían y que, después de habérselos comido, les volvian a juntar los huesos por sus coyunturas y los lloraban y los enterraban en resquicios de peñas o huecos de árboles". GARCILASO DE LA VEGA, Inca. Op. cit., p. 459. Tradução nossa.

${ }^{53}$ No original: "Como son indios de la montaña que comen carne humana, y así apenas deja el difunto que luego comienzan a comerlo que no le deja carne sino todo hueso; luego que acaba de suspirar le visten unos vestidos de plumajes que ellos les hacen $y$ quitan la plumería, y le desnudan y le lavan, y comienzan a hacer carnicería, y ellos toman el hueso y lo llevan los indios, [...] y lo meten en un árbol que llama uitaca, a donde los gusanos lo tenía hecho agujero... ”. POMA DE AYALA, Felipe Guaman. Nueva Crónica y Buen Gobierno I. Ed. y prólogo de Franklin Pease García-Yrigoyen. México: FCE, 2005. p. 218. Tradução nossa.

${ }^{54}$ No original: "Son los Chirihuanas (como se ha dicho) muy ansiosos por comer carne porque no la tienen de ninguna suerte, doméstica ni salvajina, por la mucha maleza da la tierra. Y si hubiesen conservado las vacas que el virrey le dejó se puede esperar que hayan criado muchas...”. GARCILASO DE LA VEGA, Inca. Op. cit., p. 460. Tradução nossa.

${ }^{5}$ No original: " $Y$ son tan golosos y apasionados por comer carne humana que cuando salen a saltear, (...) y si hallan pastores guardando ganado más quieren uno de los pastores que todo el hato de las ovejas o vacas”. GARCILASO DE LA VEGA, Inca. Op. cit., p. 461. Tradução nossa.

${ }^{56}$ No original: "De la poca conversación y doctrina que de la jornada pasada de los Incas pudieron tener los Chirihuanas perdieron parte de su inhumanidad, porque se sabe que desde entonces no comen a sus difuntos como solían". GARCILASO DE LA VEGA, Inca. Op. cit., p. 460. Tradução nossa. 
"Piores que bestas feras": Garcilaso de la Vega e o imaginário hispano-inca sobre os Guarani Chiriguano

Protasio Paulo Langer

${ }^{57}$ WOORTMANN, Klaas. O selvagem e a História. Heródoto e a questão do Outro. Revista de Antropologia. 2000, vol. 43, n.1. p. 13-59. Disponível em <http://www.scielo.br/pdf/ra/v43n1/v43n1a01.pdf >.

${ }^{58}$ CUNHA, Maria Manuela Ligeti Carneiro da. Imagens de índios no Brasil: o século XVI. Estudos Avançados, São Paulo, v. 4, n. 10, p. 91-110, 1990. p. 100.

59 THÉVET, André. As singularidades da França Antártica. São Paulo, Ed. Itatiaia e EDUSP, 1978, p. 199.

${ }^{60}$ No original: " $Y$ que andaban en cueros y que para juntarse en el coito no se tenía cuenta con las hermanas, hijas ni madres. $Y$ que esta era la común manera de vivir da la nación Chirihuana”. GARCILASO DE LA VEGA, Inca. Op. cit., p. 459. Tradução nossa.

${ }^{61}$ No original: "No guardan un punto de ley natural; son viciosos, tocados del vicio nefando, y no perdonan a sus hermanas; es gente superbisima; todas las naciones dicen ser sus esclavos. Comen carne humana sin ningún asco; andan desnudos”. LIZÁRRAGA, Reginaldo de. Op. cit., p.258. Tradução nossa.

${ }^{62}$ No original: “...devoran carne humana, andan desnudos (...) entregados a los más vergonzosos delitos de lujuria y sodomia”. ACOSTA, José de. Op. cit.

${ }^{63}$ RAMINELLI, R. J. Imagens da Colonização: a representação do indio de Caminha à Vieira. Rio de Janeiro: Jorge Zahar, 1996. p.95.

${ }^{64}$ WOORTMANN, Klaas. O selvagem e o Novo Mundo. Op cit., p. 97.

${ }^{65}$ No original: "Hasta para la sodomia encuentra Michele da Cuneo una explicación racional: los mansos indiani' han contraido 'questo maledeto vicio' de los feroces canibales, que 'subiugando li dicti Indiani e mangiandoli' les hicieron 'per vilipendio etiam... quello excesso, il quale poi procedendo' pudo haver 'cresciuto de l'uno in altro'. Em suma, le han cogido gusto”. GERBI, Antonello. La naturaleza de las Indias nuevas: de Cristóbal Colón a Gonzalo Fernández de Oviedo. (1978). Tradução de Antonio Alatorre. México: FCE, 1992. p. 49.

${ }^{66}$ No original: "Ahora es mayor y más forzosa la obligación que tenemos de conquistar los Chirihuanos para sacarlos de las torpezas y bestialidades en que viven y reducirlos a vida de hombres, pues para eso nos envió nuestro padre el sol'. GARCILASO DE LA VEGA, Inca. Op. cit., p. 460. Tradução nossa.

${ }^{67}$ BACZKO, Bronislaw. A imaginação social. In: LEACH, Edmund et alii. Anthropos-Homem. Lisboa, Imprensa Nacional/ Casa da Moeda, 1985. p. 312.

${ }^{68}$ No original: "Soltad esa vieja que lleváis en esa petaca que aqui nos la comeremos viva". GARCILASO DE LA VEGA, Inca. Op. cit., p. 459. Tradução nossa.

${ }^{69}$ Flores Galindo, em uma pesquisa realizada em escolas no Peru, demonstrou que a maioria dos entrevistados tinha uma imagem positiva do império incaico. Em torno de $68 \%$ consideravam-no uma sociedade e um governo justo e harmonioso. FLORES GALINDO, Alberto. Op. cit., p. 16-17.

${ }^{70}$ Agradeço à amiga Graciela Chamorro a leitura crítica da primeira versão deste artigo. Também à amiga Isabelle Combès agradeço as sugestões e o empréstimo da "chave de ouro" que conclui o texto.

\section{Referências bibliográficas}

ACOSTA, José de. De Procuranda Indorum Salute. (1577). Reeditada sob o título Predicación del evangelio en las indias. Estudio preliminar y edición del P. Francisco Mateos. Madrid: Atlas, 1954.

BACZKO, Bronislaw. A imaginação social. In: LEACH, Edmund et alii. Anthropos-Homem. Lisboa, Imprensa Nacional/Casa da Moeda, 1985.

BERNAND, Carmen \& GRUZINSKI, Serge. História do novo mundo: da descoberta à conquista, uma experiência europeia (1492-1550). 2.ed. São Paulo: EDUSP. 2002.

CASTORIADIS, Cornelius. A instituição imaginária da sociedade. Trad. Guy Reynaud. Rio de Janeiro: Paz e Terra, 1982.

CHAMORRO, Graciela. Teologia e representação: uma aproximação ecofeminista do monoteísmo. In: REIMER, Ivoni Richter. Imaginários de divindade. Goiânia: UCG, São Leopoldo: Oikos, 2008.

CUNHA, Maria Manuela Ligeti Carneiro da. Imagens de índios No Brasil: o século XVI. Estudos Avançados, São Paulo, v. 4, n. 10, p. 91-110, 1990.

FAUSTO, Carlos. Os indios antes do Brasil. Rio de Janeiro: Jorge Zahar, 2000.

FLORES GALINDO, Alberto. Buscando un inca: identidad y utopia en los Andes. Habana: Casa de las Américas, 1986. 
GARCILASO DE LA VEGA, Inca. Comentarios reales de los Incas. (1609). Edição, prólogo, índice analítico e glossário de Carlos Araníbar. Lima: FCE, 1991.

GERBI, Antonello. La naturaleza de las Indias nuevas. De Cristóbal Colón a Gonzalo Fernández de Oviedo. (1978). Trad. de Antonio Alatorre. México: Fondo de Cultura Económica, 1992.

GRUZINSKI, Serge. O pensamento mestiço. Trad. Roberto Freire d'Aguiar. São Paulo: Companhia das Letras, 2001.

LIZÁRRAGA, Reginaldo de. Descripción colonial (libro primero). (1605). Buenos Aires: Librería La Facultad, por Juan Roldán, 1916.

MARTINS, Cristiana Bertazoni. Representações do Antisuyu em El primer nueva corónica y buen gobierno de Felipe Guaman Poma de Ayala. Revista de História, 153 (2º - 2005).

MELIÁ, Bartomeu. Los Guarani Chiriguano: Nande Reko nuestro modo de ser y bibliografia general comentada. La Paz: Cipca, 1988.

MONTESINOS, Fernando de: Memorias Antiguas Historiales y politicas del Perú. Cuidada por D. Marcos Jiménez de la Espada (1644). Madrid: Imprenta de Miguel Ginesta, 1882.

MURRA, John. A estrutura política inca. In: BELLOTO, Manoel Lelo \& CORRÊA, Anna Maria Martinez. A América Latina de colonização espanhola. São Paulo: Hucitec, 1991.

. El Tawantinsuyu. In: RABIELA, Teresa Rojas \& MURRA, John (Ed..). Historia general de América Latina: las sociedades originarias. Paris: UNESCO, 1999. vol. 1.

PATLAGEAN, Evelyne. A história do imaginário. In: LE GOFF, Jaques. A história nova. São Paulo: Martins Fontes, 1990.

PESAVENTO, Sandra Jatahy. Em busca de uma outra história: imaginando o imaginário. Revista Brasileira de História, São Paulo, v. 15, no 29, 1995.

PIFARRÉ, Francisco. Los Guarani Chiriguano: historia de un pueblo. La Paz: Cipca, 1989.

RAMINELLI, Ronald José. Imagens da colonização: a representação do índio de Caminha à Vieira. Rio de Janeiro: Jorge Zahar, 1996.

ROJAS MIX, Miguel. Los monstruos: ¿mitos de legitimación de la conquista? In: PIZARRO, Ana. América Latina: palavra, literatura e cultura. São Paulo: Memorial; Campinas: Unicamp, 1993.

RUIZ, Castor M. M. Bartolomé. Os paradoxos do imaginário. São Leopoldo: Unisinos, 2003.

SAIGNES, Thierry. Historia del pueblo chiriguano. Introdução e notas de Isabelle Combés. La Paz: Plural, 2007.

THÉVET, André. As singularidades da França Antártica. Belo Horizonte: Itatiaia, São Paulo: Edusp, 1978.

WACHTEL, Nathan. Os índios e a conquista espanhola. In: BETHELL, Leslie (Org.). História da América Latina: América Latina Colonial. São Paulo: Edusp; Brasília; Funag, 1998, p.135-194.

WOORTMANN, Klaas. O selvagem e a História. Heródoto e a questão do Outro. Revista de Antropologia. 2000, vol. 43, n.1. p. 13-59. Disponível em <http://www.scielo.br/pdf/ra/v43n1/v43n1a01.pdf >. O selvagem e o Novo Mundo: ameríndios humanismo e escatologia. Brasília: UNB, 2004.

\section{RESUMO}

No presente artigo propomos uma análise do imaginário de Garcilaso de la Vega sobre os Chiriguano - povo guarani falante que, por volta do século $X V$, se estabeleceu nas fronteiras do império andino. O tenaz enfrentamento que travaram contra os exércitos imperiais incaicos e, posteriormente, contra os hispânicos ensejou que o cronista Garcilaso de la Vega descrevesse os Chiriguano como a antítese da civilização. Nossa análise incide sobre como esse cronista mestiço abordou os Chiriguano, no intuito de tecer similaridades entre o imaginário cristão e o inca.

Palavras-chave: imaginário; barbárie; Chiriguano; Garcilaso de la Veja; Incas. 


\begin{abstract}
In the present article, we propose an analysis of the imaginary of Garcilaso de la Vega about the Chiriguano - a speaking Guarani people who, around the $15^{\text {th }}$ century, settled in the borderline of the empire of the Andes. The fierce battles in which they engaged against the imperial inca armies and later against the Hispanic people led the chronicler Garcilaso de la Vega to describe the Chiriguano as the antitheses of civilization. Our analysis shows how this mestizo chronicler viewed the Chiriguano, hoping to point out similarities between the Christian imaginary and the inca imaginary.

Keywords: imaginary; barbarity; Chiriguano; Garcilaso de la Veja; Incas.
\end{abstract}

